\title{
MISTIFIKASI RITUAL SISTEM PERTANIAN TRADISIONAL MASYARAKAT AJATAPPARENG, SULAWESI SELATAN
}

\author{
Ritual Mystification of Traditional Farming System \\ on Ajatappareng Community, South Sulawesi
}

\author{
Nani Somba ${ }^{1 \mathrm{a}}$, Syahruddin Mansyur ${ }^{1 \mathrm{~b}}$, Muhammad Nur ${ }^{2}$ \\ ${ }^{1}$ Balai Arkeologi Sulawesi Selatan \\ J1. Pajjaiyang No. 13 Sudiang Raya Makassar, Indonesia \\ anani.somba@kemdikbud.go.id; \\ bsyahruddin.mansyur@kemdikbud.go.id \\ ${ }^{2}$ Departemen Arkeologi, Universitas Hasanuddin \\ J1. Perintis Kemerdekaan, Km. 10, Makassar, Indonesia \\ mnur@unhas.ac.id
}

Naskah diterima: 20/03/2019; direvisi: 28/03-09/05/2019; disetujui: 10/06/2019

Publikasi ejurnal: 01/06/2019

\begin{abstract}
The Ajatappareng region is known as the most important rice producer in South Sulawesi. Historical sources and archaeological evidence show that agricultural tradition in this region has been going on for at least the $14^{\text {th }}$ century. In that time span, the Ajatappareng community carried out an agricultural system as a system of knowledge passed down from generation to generation. This study aims to obtain a record of knowledge related to the traditional farming system of the Ajatappareng community. It used etnographic method with data collection techniques through in-depth interviews and literature studies. The data obtained illustrates the belief system in the traditional farming system of the Ajatappareng community that has various stages and processes. This belief system is illustrated throught a series of rituals that become an integral part of Ajatappareng community's agricultural system. In the process, this agricultural system has undergone various changes along with the development of knowledge. The recording of knowledge about agricultural traditions, belief system and the changes that surround them are important given the global trend that promotes sustainable food agriculture management.
\end{abstract}

Keyword: agricultural, system, ritual, traditional, Ajatappaerng.

\begin{abstract}
Abstrak
Wilayah Ajatappareng dikenal sebagai penghasil beras paling utama di Sulawesi Selatan. Sumbersumber sejarah dan bukti-bukti arkeologi yang ada menunjukkan bahwa tradisi pertanian di wilayah ini telah berlangsung setidaknya sejak abad ke-14. Sejak itu pula, masyarakat Ajatappareng menjalankan sistem pertanian sebagai pengetahuan yang diwariskan secara turun temurun. Penelitian ini bertujuan untuk menjelaskan pengetahuan terkait sistem kepercayaan dalam pertanian tradisional masyarakat Ajatappareng. Penelitian menggunakan metode etnografi dengan teknik pengumpulan data melalui wawancara mendalam dan diikuti studi literatur. Sistem pertanian tradisional masyarakat Ajatappareng memiliki berbagai tahapan dan proses, pengetahuan masyarakat tidak hanya masalah teknis, tetapi juga menyangkut sistem kepercayaan yang diwujudkan melalui rangkaian ritual. Sistem pertanian ini telah mengalami berbagai perubahan seiring dengan perkembangan pengetahuan masyarakat. Rekaman pengetahuan tentang tradisi pertanian, sistem kepercayaan, serta perubahan-perubahan yang melingkupinya, menjadi penting mengingat tren global yang mengedepankan pengelolaan kawasan pertanian pangan berkelanjutan
\end{abstract}

Kata Kunci: pertanian, sistem, ritual, tradisional, Ajattappareng. 


\section{PENDAHULUAN}

Bugis merupakan etnik terbesar di Pulau Sulawesi (Pelras, 2006), mendiami 11 Kabupaten di Sulawesi Selatan, yaitu Kabupaten Pinrang, Parepare, Sidrap, Barru, Pangkep, Maros, Soppeng, Bone, Wajo, Sinjai, dan Bulukumba. Bugis menempati daerah pesisir barat, dataran rendah, dataran tinggi dan pesisir timur Sulawesi Selatan. Sebagian besar masyarakatnya mengembangkan kegiatan pertanian padi. Beberapa ahli mengungkapkan bahwa aktivitas pertanian telah berlangsung sejak abad ke-14 yang ditandai oleh penemuan bukti padi di Situs Allangkanange di Wajo dan Situs Tinco di Soppeng (Bulbeck \& Caldwell, 2008; Hasanuddin, 2015; Macknight, 1983).

Penduduk Bugis menempati wilayah geografis yang berbeda-beda, sehingga terdapat kebiasaan dan tradisi bervariasi antara setiap lokalitas orang Bugis, meskipun sepintas lalu terkesan tidak terlalu tampak. Ada beberapa kondisi yang melatarbelakangi munculnya perbedaan tradisi pertanian pada setiap lokalitas Bugis tersebut, seperti perbedaan geografis, curah hujan, angin, perbedaan musim dan potensi hidrologi. Perbedaan tradisi pertanian pada setiap lokalitas Bugis tersebut ditandai dua hal, yaitu tradisi menulis pada daun lontar atau kertas sejak abad ke-17, dan kuatnya tradisi pertanian tersebut melekat pada setiap lokalitas Bugis. Tradisi menulis naskah dalam masyarakat Bugis berhasil mendokumentasikan peristiwa dan pengetahuan masyarakatnya, termasuk aspek-aspek yang terkait dengan pertanian pada masa lampau.

Pada kesempatan ini akan membahas sistem pertanian tradisional masyarakat Bugis di wilayah barat Danau Tempe atau biasa dikenal dengan sebutan Ajatappareng (Druce, 2005; Latif, 2014; Pabitjara, 2006). Ajatappareng merupakan sebuah persekutuan kerajaan yang terbentuk pada abad ke-18 yang beranggotakan: Kerajaan Sawitto, Suppa, Sidenreng, Alitta, dan
Rappang. Sekarang, kelima kerajaan ini berada di dua kabupaten, yaitu Kabupaten Sidenreng Rappang dan Kabupaten Pinrang.

Wilayah Ajatappareng sejak dulu dikenal sebagai penghasil beras di Sulawesi Selatan. Potensi pertanian itu pula yang menjadi salah satu alasan bagi Kerajaan Gowa menaklukkan wilayah Ajatappareng (Suppa, Sawitto, dan Sidenreng) pada abad ke-16, diyakini dilatarbelakangi oleh upaya Gowa menguasai sumber pangan wilayah tersebut (Latif, 2014, p. 11; Poelinggomang, 2002, p. 26). Demikian juga catatan Tome Pires abad ke-16 mengungkapkan bahwa pedagang-pedagang Bugis datang ke Malaka, Pahang, dan Siam membawa beras dengan kualitas bagus sebagai salah satu komoditi dagang (Cortesao, 2015, p. 313).

Ajatappareng khususnya Suppa juga merupakan bandar niaga pada periode awal abad ke-16, utamanya setelah Malaka jatuh ke tangan Portugis tahun 1511 dan sebelum kebangkitan Makassar sebagai bandar niaga pada pertengahan abad ke-16 (Latif, 2014, p. 10). Hingga abad ke-19, peran Ajatappareng sebagai penghasil beras terus bertahan. Laporan Gubernur Celebes pada 7 April 1892, menyebutkan bahwa produksi beras di Ajatappareng mengalami surplus sehingga dapat dikirim untuk memenuhi permintaan di wilayah lain di Hindia Belanda (Morris, 1982). Sumber-sumber historis yang ada juga menunjukkan tradisi pertanian khususnya padi sawah telah berlangsung lama dalam masyarakat di wilayah Ajatappareng.

Sistem pertanian bagi masyarakat dengan latar budaya agraris dipahami sebagai cara atau teknik mengelola sumbersumber alam untuk peningkatan produktivitas hasil pertanian. Secara umum, sistem pertanian dalam pengelolaan pertanian jenis padi sawah memiliki kesamaan dengan tata cara yang dilakukan di beberapa daerah, meski tetap ada perbedaan-perbedaan yang menjadi karakteristik sistem pertanian setempat. Sistem pertanian masyarakat di Indonesia 
berkembang dengan karakter masingmasing, meskipun beberapa di antaranya tetap memiliki kesamaan-kesamaan pada aspek tertentu. Sistem pengetahuan masyarakat terkait budaya agraris di Nusantara masih ada yang tetap dipertahankan. Hal ini dapat dilihat pada sistem subak atau pengelolaan air irigasi tradisional bagi masyarakat di Bali, serta upacara-upacara tradisional yang terkait dengan pertanian seperti mendak/mapag toya dan ritual niduhen bagi masyarakat tradisional yang ada di Bali, ritual rabu nehah bagi masyarakat Gampong Paloh Kayee Kunyet di Aceh, sistem pertanian masyarakat Saleman di Maluku dan Tapanuli Utara yang tetap mempertahankan sistem tradisional untuk pemenuhan kebutuhan sehari-hari (Afandi, Arjani, \& Kaler, 2017; Maulida, 2017; Nurung \& Pratiwi, 2011; Purwanto, 2010; Sartini, 2017).

Diskusi tentang sistem pertanian di Indonesia, setidaknya dapat diuraikan antara lain tentang; a) Sistem pertanian, mulai dari aturan dan proses pengolahan sawah, proses penanaman padi, sistem pengairan sawah, hingga sistem panen dan bagi hasil; $b$ ) Hak kepemilikan lahan persawahan; serta $c$ ) Sistem kepercayaan dalam pertanian tradisional. Pada dasarnya, wawasan pengetahuan dan kebudayan pertanian etnik Bugis adalah bagian dari kekayaan etnografis Indonesia. Penelitian mendalam tentang budaya pertanian Bugis pada lokalitas Ajatappareng, berdasarkan data BPS tahun 2018 menunjukkan bahwa wilayah ini merupakan penghasil beras tertinggi di Sulawesi Selatan (BPSP, 2018). Pembahasan artikel ini difokuskan pada sistem kepercayaan dalam budaya pertanian tradisional khususnya bagi masyarakat Ajatappareng. Oleh karena itu, pembahasan tentang fenomena budaya pertanian masyarakat Ajatappareng dibagi menjadi a) sistem kepercayaan dalam pertanian tradisional masyarakat Ajatappareng, b) mistifikasi ritual sistem pertanian tradisional masyarakat Ajatappareng, c) transformasi budaya pertanian, dan $d$ ) pudarnya ritual pertanian.

\section{METODE PENEITIAN}

Penelitian ini bertujuan untuk menghasilkan gambaran tentang sistem kepercayaan dalam pertanian tradisional dan perubahan-perubahan yang terjadi dalam budaya pertanian masyarakat Ajatappareng. Penelitian ini menggunakan pendekatan kualitatif. Pemerolehan data-data dilakukan melalui studi pustaka untuk memperoleh referensi yang sesuai, observasi pada lokasi arkeologis, kritik ekstern dan intern pada data naskah serta wawancara terbuka dan mendalam. Data-data kemudian diidentifikasi dan dihubungkan antara satu dengan lainnya untuk memperoleh gambaran secara holistik dan memperbanyak pemahaman secara mendalam, serta menjelaskannya secara kualitatif (Moleong, 2008, p. 31).

\section{HASIL DAN PEMBAHASAN}

\section{Sistem Kepercayaan dalam Pertanian Tradisional Masyarakat Ajatappareng.}

Dalam mitologi Bugis, yang berkenaan dengan padi, peranan mitos Dewi Sangiang Serri sangatlah penting. Terlebih adanya kenyataan bahwa masyarakat Bugis hanya mengenal upacara adat pertanian untuk padi saja. Demikian pula bahwa teknik pertanian tradisional masyarakat Bugis selalu menempatkan petuah-petuah para tetua dan ahli pertanian sebagai aturan yang harus dijalankan. Oleh karena itu, siklus yang baku pada pengolahan sawah selalu ditandai dengan ritual-ritual tertentu secara teratur (Pelras, 2006, p. 276).

Sistem kepercayaan dalam pertanian tradisional masyarakat Bugis juga mengenal penentuan waktu yang baik. Pelras (2006), menyebut bahwa naskah pertanian Bugis yang disebut lontara pallaonrumang atau allaonrumangeng berisikan seluruh khasanah pengetahuan pertanian yang 


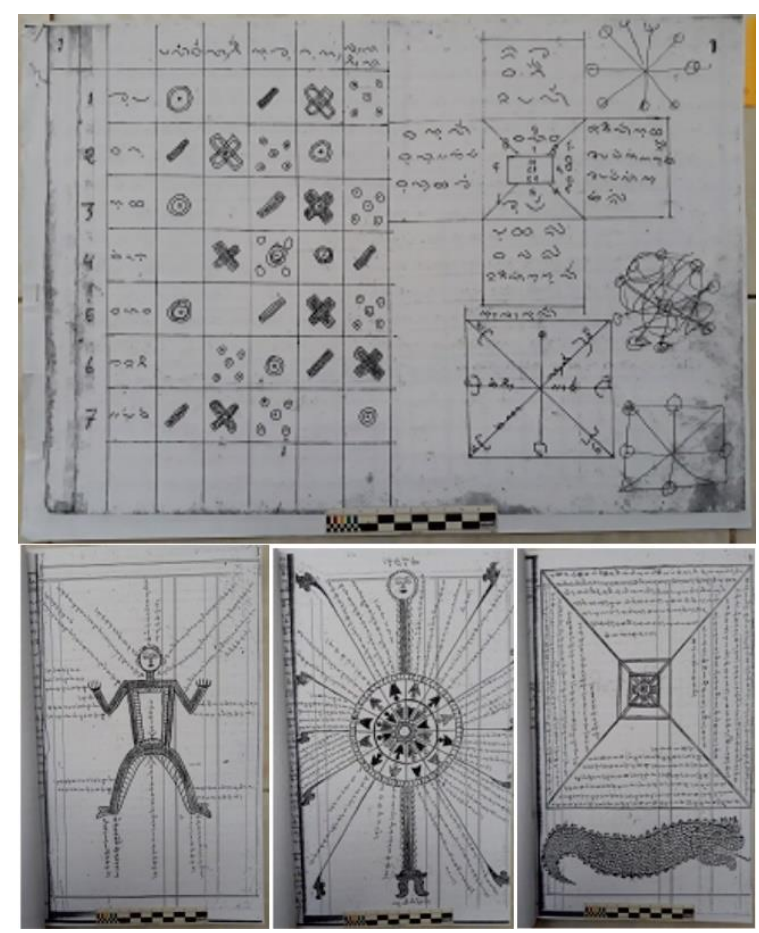

Gambar 1. Lontara Kutika, jenis lontara yang menjelaskan tentang penentuan hari baik, koleksi pribadi milik Bapak Mahmud, Sawitto (atas). Lontara Kutika, koleksi pribadi milik Drs. Andi Muhammad Saleh Pasanrangi (Petta Saleh), Sidenreng (bawah) (Sumber: Foto Repro Dokumen Penelitian Balai Arkeologi Sulawesi Selatan, 2018).

berasal dari para nenek moyang (toriolo). Naskah ini berisi pengamatan fenomena alam dan rasi bintang pada setiap musim tanam, serta berbagai penjelasan mengenai segala sesuatu yang harus dilaksanakan pada setiap periode yang didasarkan atas sistem penanggalan matahari (gambar 1). Nama hari yang digunakan merujuk pada sistem kalender Arab, sementara nama bulan merujuk pada bahasa Portugis. Dalam sistem penentuan waktu $\mathrm{ini}^{1}$, terdapat sembilan rasi bintang yang memegang peran penting, yaitu: Tekko Soro; Worong-mporong; Warawara'; Tanra Tellu; Manu'; Watang-mpata; Empang-e' (empangnge) atau Bola Keppang; Walu Janda; dan Lambaru (lambaru'). Namun, naskah penanggalan

\footnotetext{
1 Versi lain tentang pembagian waktu, lihat Badaruddin, et. al., (1986), "Sistem Ekonomi Tradisional sebagai Perwujudan Tanggapan Aktif
}

tersebut hanya berlaku lokal karena adanya perbedaan musim hujan untuk masingmasing daerah di Sulawesi Selatan (Pelras, 2006, p. 278).

Selanjutnya proses pengolahan sawah dimulai dengan kegiatan pembukaan lahan persawahan baru yang dikenal dengan istilah makkabekka' galung atau ekstensifikasi pada masa lalu. Makkabekka' adalah proses membuka lahan persawahan dengan membabat belukar dan pohon-pohon yang berada pada lahan tertentu. Sebelum memulai mengolah atau menanam padi, masyarakat biasanya tidak hanya mengandalkan pada tata cara pengolahan, tetapi juga sangat bergantung pada ritual yang berhubungan dengan doa-doa, seperti melakukan ritual mappalili. Pada dasarnya, mappalili, atau maccera' tana dipimpin oleh sanro galung dengan membuat sesajen yang terdiri dari telur, daun waru (mparu), pinang (alosi), daun sirih (rekko ota), beras (berre'), kapur (puale) dan indo/datu ase. Sesajen ini kemudian diletakkan di dalam walasaji pada sudut sawah, dimana saat itu pula dipotongkan seekor ayam sebagai paccera tanah dengan doa keselamatan untuk padi:

Nasalama na mappasalama kuduppai akkaresongengku, kualengngi olota baca doang salama natarima Puang Allahtaala (Wawancara: La Sewa, 58 tahun, petani, 24 Oktober 2018).

Setelah ritual mappalili dilakukan, maka dimulailah membajak sawah dengan menggunakan alat bajak (rakkala) yang ditarik oleh dua ekor kerbau. Alat pengolahan sawah yang lebih modern adalah traktor tangan atau biasa disebut dengan dompeng (dalam istilah lokal Bugis).

Proses selanjutnya adalah proses penanaman padi yang juga sarat dengan rangkaian ritual-ritual. Sebelum menanam padi, biasanya terlebih dahulu menyiapkan benih dari gabah atau padi yang sudah

Manusia terhadap Lingkungannya: Daerah Sulawesi Selatan". Departemen Pendidikan dan Kebudayaan. Hal. 38-39. 
dipisahkan dari tangkainya (lengoreng), pemisahan gabah dari batangnya bisa dilakukan dengan dua cara, yaitu dengan ditumbuk di lesung atau diinjak-injak (direse'). Sebelum di turunkan ke sawah, dilakukan perendaman benih selama dua malam, kemudian diangkat untuk disimpan di atas rumah, biasanya ditempatkan di tiang tengah rumah (possi bola), dan dikenal dengan istilah mappatinro bine, biasanya disertai daun sirih (rekko' ota) dan lampu terbuat dari kemiri yang ditumbuk, kemudian dipilin menjadi sebuah lilin selama satu malam. Hingga dasawarsa 1960an, bibit (bine) yang akan ditanam (termasuk jenis ketan atau ase pulu') masih mengambil dari berbagai varietas lokal $^{2}$ sisa panen sebelumnya. Masa pertumbuhan varietas tradisional berlangsung selama 110-150 malam (Pelras, 2006, p. 279). Setelah padi berusia sekitar sepuluh hari maka petani datang lagi mengunjungi padinya pada waktu sore (malam jumat) dengan membaca doa:

"enreni kobolata tudangemmu, pura paccingni bolata, pura ballani tappere uddaningmu, muliwu manengngi maggoro goroe tikkeng ase" (Wawancara: La Sewa, 58 tahun, petani, 24 Oktober 2018).

Begitu pula, apabila padi mulai berisi dewasa (anaddarani), petani kembali lagi menyemburkan air dengan daun sirih (mangeppi), kemudian membaca doa-doa keselamatan (pakkuru sumange), sebagai pengharapan dalam menyambut buah padi yang mulai berisi.

Selain berbagai bentuk ritual dalam rangkaian proses pengolahan sawah, masyarakat Ajatappareng di Sidenreng juga memiliki aturan atau pesan yang harus diikuti agar hasil panen mendatangkan

\footnotetext{
${ }^{2}$ Variates padi lokal yang dikenal masyarakat Bugis sebelum penggunaan varietas padi unggul, diantaranya: ase unnyi, ase bakko, ase loco-loco, ase bulukumba, ase bekka, ase lambau, dll (Badaruddin, Mappasere, \& Aminullah, 1986, p. 67)
}

kebaikan bagi semua anggota masyarakat. Aturan ini dapat kita jumpai pada salah satu lontara La Towa yang menjelaskan tentang aturan-aturan dan pesan-pesan dari Nene, Mallomo ${ }^{3}$ tentang mula-mula diterapkan aturan yang baik di Sidenreng mengenai aturan bagi orang yang bekerja di sawah, seperti yang dijelaskan di dalam lontara berikut:

"dari hal orang yang bekerja sawah, apabila tiga bulan lagi, maka waktu orang bekerja sawah, duduklah engkau sekalian orang Sidenreng memutuskan sekalian perkara sawah, yang telah dibicarakan dan janganlah terima orang yang baru datang mengadukan perkara sawahnya. Janganlah bicarakan pada tahun itu, melainkan kalau sudah memotong padi, barulah ini mulai membicarakan perkara sawah, kalau dua bulan lagi waktunya orang bekerja sawah, berkumpul pulalah orang Sidenreng dan beritahukan kepada Arung Matowa, supaya janganlah ada membicarakan perkara sawah. Orang yang mengerjakan sawah itu pada tahun yang lalu dialah mengerjakan sawah itu tahun. Demikianlah juga pada sekalian Lili', dan kepada sekalian negeri yang mengikut di Sidenreng menyiarkan perintah yang disepakati itu. Kalau sudahlah berkumpul di Sidenreng, pulanglah masing-masing di negerimu engkau orang Lili', dan beritahukan pada anak negerimu supaya jangan ada yang membicarakan sawah, dan beri pengajaran kepada anak buahmu, dari hal aturan bekerja sawah. Suruh juga hadat memberitahukan pada waktu pasar besar di Sidenreng dan tentukanlah pula seorang pabbicara,

\footnotetext{
${ }^{3}$ Nene Mallomo atau Nene Allomo adalah seorang tokoh legendaris yang menjadi tokoh panutan masyarakat Sidenreng Rappang yang dikenal memiliki sikap adil dan bijaksana.
} 
yang mengurus perkara sawah, dan dia yang menurunkan engkau di sawah engkau sekalian Matowa, orang bekerja sawah (Baoesat, 2006) "Lontara Terjemahan La Towa, hal. 104, Koleksi Petta Saleh"

Artinya, bahwa masyarakat petani sebelum memulai pekerjaan turun sawah, harus selalu berkumpul antara para Matowa dan masyarakat tani, untuk membicarakan dan menentukan waktu yang baik untuk memulai persiapan pengolahan padi sawah. Penentuan waktu ini dilakukan melalui kesepakatan bersama untuk menghindari terjadi kegagalan panen, sehingga tidak ada yang saling menyalahkan dan ketika panen padi melimpah seluruh masyarakat petani akan menerima secara bersuka ria bersamasama.

Sebelum memulai mengerjakan sawah, diharapkan para petani dengan Matowa, untuk saling memohon kebaikan, saling memaafkan, tolong menolong dan tidak boleh ada kesalahpahaman diantara mereka. Artinya, ketika dalam menjalankan pekerjaan atau mengolah sawah nantinya, tidak ada lagi berpikir yang kurang baik diantara mereka tetapi, bekerja dengan hati yang lega, bersih dan tenang.

Setelah kesepakatan antara Matowa, Pabbicara dan Addatuang terjadi, maka wajiblah dimulai pengolahan sawah adat yang disebut dengan sawah Lasalama. Para penentu kebijakan yang mewakili masyarakat petani mulai mengelilingi sawah Lasalama sebagai tanda, bahwa pengolahan sawah sudah harus dikerjakan. Hubungan antara masyarakat petani sawah dengan para, Matowa, Pabbicara dan Addatuang, berjalan dengan harmonis. Adapun niat yang dimaksudkan itu adalah;

"Kami sengaja berjalan keliling La salama (nama tanah sawah) kami tanami padi, apabila kami mendapatkan hasil yang banyak itu selamat juga, kami tentu sembelih kerbau hitam dan kambing dan kami makan berkumpul dengan orang banyak di sawah ini. Barulah kami bawa hasilnya itu ke rumah, dan kami makan bersama anak istri dan cucucucu dan dikuatkan oleh hadat dan syarat, dan kami makan dengan panjang umur kami, mengerjakan suruhan dan menjauhkan diri dari larangan dan melakukan kewajiban hadat dan syarat". Apabila hendak mengerjakan La Salama kumpulkanlah perkakas yang dipakai oleh kerbau perkakas yang dipakai oleh kerbau yang bekerja sawah di bawah kolong pertengahan rumah, kalau memulai bekerja, sembelihlah seekor ayam merah untuk kerbau itu (kerbau dicera) ayam merah itu, kuning kakinya dan kuning paruhnya dan seekor ayam yang kuning bulunya, kuning kakinya dan paruhnya, kamu niatkan dalam hatimu, bahwa darah dari ayam itu untuk jin dan setan penjaga sawah itu, dagingnya adalah untuk dewata.

Kalau dibawalah perkakas kerbau itu pada sawah itu pada kerbaumu, berkelilinglah jalan ke kandang tiga kali, hadapkan ke arah negeri. Kalau hendaklah mengenakan perkakas yang dipakai kerbau menjaga sawah pulangkanlah dulu kerbaumu itu pada tempatnya dan keluarkan perkakas yang dipakainya, dan ambillah tanah yang ada dekat kerbaumu dan engkau sapukan pada badanmu dan di badan kerbaumu, supaya tidak kena penyakit padimu itu. Kalau engkau sapukan tanah di badanmu engkau berkata pada tanah itu demikian: "kamu yang disapukan atau kamu yang disapui, isipuru nama sebenarnya air itu, air yang memelihara kepadamu padi, angin yang menjadikan engkau besar dan awan yang menyusukan padamu (padi). Noeng nama kami. Dari sebab itu maka bersamaan sifat dengan padi, 
air dan lain-lain, datang dari Tuhan. Peliharakan badan kami di dalam sifatnya Tuhan Allah. Adapun rumput yang tersangkut pada gigi bajak itu ambillah juga engkau peliharakan baik-baik. Apabila orang yang bekerja sawah itu kena penyakit ambillah rumput itu campur dengan sirih yang bertemu uratnya tiga lembar dan kunyah sampai halus baru sapukan pada badan orang sakit itu. Engkau ambil segenggam tanah, banyaknya seperti sesuap nasi, baru engkau menghadap matahari dan berkata demikian, "Apabila tertahan bulan yang terbit, barulah tertahan juga reski kami datang dari Tuhan Allah".

Katanya raja yang dahulu yang menjadikan besar kerajaannya negeri Sidenreng. Apabila musim panas itu lewat, iyatuh sudahlah waktunya datang hujan, tetapi tidak ada hujan yang turun hanya panas saja, selamalamanya, dan kena penyakit padi itu atau ada satu binatang merusakkan dan memakannya, sepakatlah engkau orang Sidenreng keluar di padang berkumpul makan semuanya bersama, dan engkau lihat dari mana asal kecelakaan itu. Kalaulah sudah didapat sebabnya itu sembelihlah kerbau hitam, dan berikan kepada orang yang berkuasa di sawah, dan mohonkan maaf dari kesalahan pada dewata, barulah disembelih kerbau itu dan dimakan bersama-sama orang yang berkumpul di padang itu (Baoesat, 2006) "Lontara Terjemahan La Towa, hal. 105-6, Koleksi Petta Saleh".

Demikian aturan-aturan yang diajarkan oleh Nene' Mallomo yang berhubungan dengan tata cara dan larangan yang ditetapkan bagi seluruh pekerja sawah. Selain pasal menentukan aturan Nene'
Mallomo di Sidenreng, yaitu ade' puraonro di Sidenreng dari pabbicara aruae, no' rakkalana (yang mengerjakan sawahnya Addatuang). Apabila orang dibenci oleh Matowanya dan tidaklah turun bekerja pada sawah Lasalama dan tidaklah pula bersama sama Matowanya bekerja di rumah Salassa atau di Ale' Karaja dan tidak mau bernaung di bawah bendera Matowanya (tidak mau mengikut perintah) dan dia hendak pindah mengikut perintah Matowa lain di Sidenreng, disuruhlah orang itu merombak dan mencabut tiang rumahnya serta dipindahkan rumahnya itu ke negeri tempatnya mengikut perintah.

Masyarakat yang tidak mau mengikuti lagi aturan-aturan dari yang sudah diterapkan oleh kerajaan/addatuang, maka masyarakat itu dipersilahkan untuk pergi ke negeri itu, dengan membawa rumahnya sekalian.

\section{Mistifikasi ${ }^{4}$ Ritual dalam Sistem Pertanian Tradisional.}

\section{a. Mappalili}

Ritual mappalili adalah satu bentuk upacara ritual yang berkaitan dengan keberadaan mitos tentang Dewi Sri 'Sangiang Serri', mitos ini berhubungan dengan kepercayaan masyarakat, awal munculnya tanaman padi, terutama tentang tata cara pengolahan sawah dan penanaman padi. Jadi sebelum masyarakat memulai aktifitas pertanian, masyarakat petani sudah melakukan suatu ritual yang namanya mappalili, ritual bersifat sakral (suci), sebagai pertanda, bahwa mereka sangat menghormati dan menghargai yang namanya tanaman padi, sebagai sumber pemenuhan kebutuhan hidupnya. Keyakinan masyarakat tani akan ritual mappalili, sebagai usaha memohon pertolongan dari roh para leluhur nenek moyang mereka, dan kuasa campur tangan Sang Maha Kuasa sebagai pencipta segala-galanya. Tempat

\footnotetext{
${ }^{4}$ memandang sesuatu sebagai misteri.
} 




Gambar 2. Temuan lumpang batu di Watang Sidenreng (atas) dan Alitta (bawah). Awalnya, lumpang batu berfungsi sakral sebagai tempat pelaksanaan ritual pertanian (Sumber: Balai Arkeologi Sulawesi Selatan, 2018).

pelaksanaan ritual mappalili sangat identik dengan tempat-tempat yang dianggap sakral atau makam tokoh yang dihormati atau tempat turunnya Tomanurung (Somba \& Nur, 2016, p. 225). Di beberapa tempat di Ajatappareng, lokasi yang dapat dicontohkan sebagai tempat pelaksanan ritual ini adalah Lawarangparang di Suppa, Arajang Sawitto di Sawitto, Makam Pallipa Pute di Katteong (Langga), dan Makam Petta Maupe di Katteong (Langga), dan Makam Petta Maupe di Watang Sidenreng (Mansyur et al., 2018; Tim Penelitian, 2012). Salah satu temuan arkeologis yang umum dijumpai di situs-situs pemukiman adalah temuan lumpang batu yang memiliki fungsi profan sekaligus fungsi sacral (gambar 2). Fungsi profan tampak pada penggunaan lumpang batu sebagai media untuk mengolah hasil pertanian. Sementara fungsi sakral adalah sebagai media dalam pelaksanaan upacara atau ritual yang berkaitan dengan pertanian.

Setiap upacara ritual mappalili selalu ada pemimpin upacara, seperti halnya pada upacara ritual lainnya. Ritual mappalili dipimpin oleh seseorang yang dianggap mempunyai kelebihan dalam hal tertentu biasa disebut Sanro Wanua/Uwak, Sanro Wanua ini, dianggap punya kemampuan dan pengetahuan tertentu mengenai penentuan hari-hari baik untuk memulai aktifitas pertanian, pada sisi lain. Sanro Wanua juga dianggap dapat berhubungan langsung dengan roh-roh halus para leluhur yang dapat membantu dan melindungi masyarakat dalam berbagai hal-hal buruk pada kehidupan masyarakat. Berbeda dengan daerah lain, di wilayah Ajatappareng, ritual mappalili tidak dipimpin oleh seorang Bissu sebagaimana dikenal di daerah lain. Meski demikian, kedua pemimpin ritual ini yaitu Sanro Wanua dan Bissu tetap memiki peran dan prosesi ritual yang sama.

Dalam konteks prosesi ritual, terjadi mistifikasi ritual dimana bissu atau sanro wanua berfungsi sebagai aktor yang memerankan peran pendeta atau pemimpin ritual tertentu yang dipertunjukkan pada audiens (masyarakat yang mengikuti prosesi mappalili). Mistifikasi ritual dalam proses mappalili sesunguhnya bertujuan untuk menjaga jarak sosial antara bissu sebagai pemimpin ritual dengan masyarakat sebagai peserta ritual agar senantiasa dianggap "makarama" (Bahfiarti, 2011, pp. 165169).

Upacara ritual "Mappalili”, berasal dari kata palili' yang berarti usaha masyarakat petani untuk melindungi tanaman padi dari sesuatu yang dianggap akan mengganggu atau merusak tanaman, sehingga dilakukanlah satu bentuk permohonan dan penghormatan terhadap Sang Maha Kuasa. Ritual Mappalili', dari hasil wawancara langsung dengan informan kunci bapak Andi Muhammad Saleh 
Pasanrangi, bahwa mappalili adalah termasuk ritual maccera tanah (gambar 3). Setiap ritual yang disertai dengan kata maccera, berarti selalu disertai dengan pemotongan hewan diantaranya; kerbau, kambing dan ayam. Jenis hewan yang dipotong tergantung kemampuan dan kesepakatan masyarakat yang melaksanakan ritual. Upacara ritual seperti ini, sekarang sudah susah dijumpai lagi, akibat pengetahuan dan wawasan masyarakat semakin berkembang. Masyarakat petani sawah yang masih melaksanakan ritual mappalili, menganggap bahwa, bagaimanapun mereka tetap harus mengingat pesan-pesan nenek moyang mereka. Sebahagian masyarakat petani sawah lainnya menganggap, bahwa itu merupakan perbuatan syirik yang bertentangan dengan syariat Islam (Fajriyani, 2015, p. 60).

Saat ini, nilai sakral ritual seperti itu tidak lagi menjadi begitu penting bagi mereka, meskipun beberapa petani masih melakukan secara sendiri-sendiri di rumah, mereka hanya melakukan doa di rumah secara sendiri-sendiri dan memohon akan kelancaran dan keberhasilan panen mereka nantinya. Ilmu pengetahuan dan wawasan berfikir yang semakin berkembang, menjadi faktor tersendiri yang mempengaruhi pola pikir masyarakat berubah dan secara lambat laun dapat mempengaruhi pola pikir masyarakat tani, untuk tidak lagi melaksanakan ritual yang berhubungan dengan hal-hal berbau mistis (sakral). Pada sisi lain, ritual mappalili memiliki nilai-nilai positif terutama nilai-nilai sosial, yaitu solidaritas gotong royong, kebersamaan sosial dan ekonomi. Tradisi ini membangun kebersamaan dan rasa solidaritas antar warga dimana dalam pelaksanaan tradisi ini warga secara bersama-sama saling menikmati serta berpartisipasi demi kelancaran acara mappalili tanpa melihat status sosial. Nilai ini dapat menumbuhkan


Gambar 3. Buju Tompo'e, sumur tua penanda situs Lawarangparang, salah satu titik utama dalam pelaksanaan ritual Mappalili oleh masyarakat Suppa, dan pohon ritual di lokasi Situs Lawarangparang (atas). Makam Pallipa Pute, tempat pelaksanaan ritual Mappadendang masyarakat Katteong/Langnga (kiri bawah). Makam Petta Maupe, tempat pelaksanaan ritual Mappalili dan ritual-ritual keselamatan lainnya/Mappangolo atau Massorong (kanan bawah) (Sumber: Balai Arkeologi Sulawesi Selatan, 2018). 
rasa persaudaran diantara mereka, serta saling bersilaturahmi dan mengakrabkan sesama anggota masyarakat (Asrianensi, 2014, p. 45).

Sebagai sebuah manifestasi ritual, mappalili (gambar 4) memiliki beragam makna dalam kehidupan orang Bugis, seperti: kesetiaan dan kepercayaan; penghargaan terhadap leluhur; sebagai tanda bagi petani; dan penghormatan (Khaedir, 2018, pp. 68-76). Mappalili' merupakan
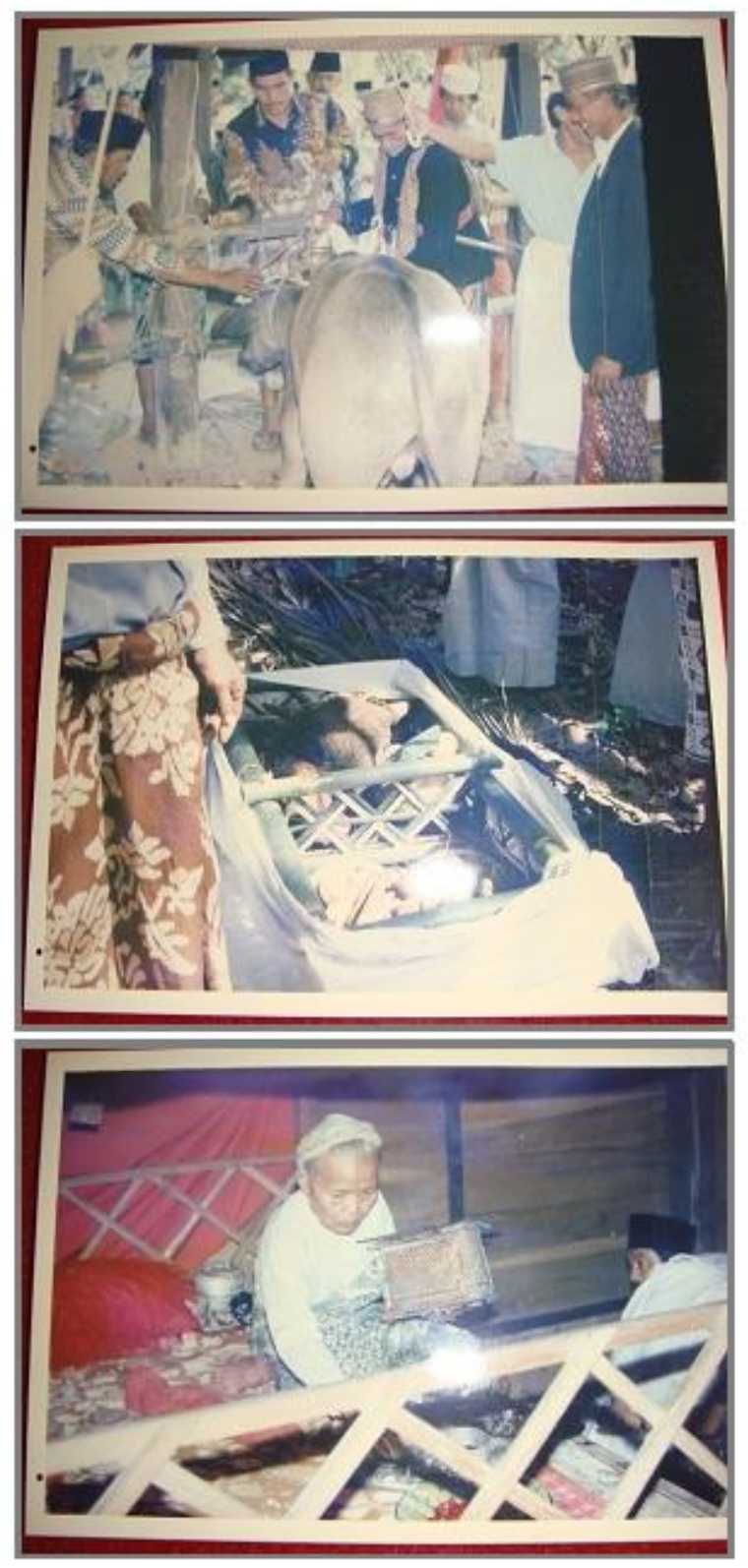

Gambar 4. Dokumentasi lama prosesi mappalili yang dilaksanakan oleh masyarakat Ajatappareng, dalam proses ini peran Sanro masih sangat sentral dan sakral (Sumber: Repro koleksi Dinas Pendidikan dan Kebudayaan Kabupaten Pinrang, 2018).

wujud permohonan dan kepasrahan manusia terhadap Sang Maha Pencipta, sehingga segala sesuatunya harus selalu berpedoman pada pesan-pesan para leluhur mereka sebagai penghormatan. Rasa hormat ini dimanifestasikan dalam bentuk ritual mappalili', sehingga apapun yang akan dilakukan berkaitan dengan tanaman padi sawah, masyarakat petani sawah tidak pernah lupa untuk melakukan ritual mappalili mulai dari membuka lahan
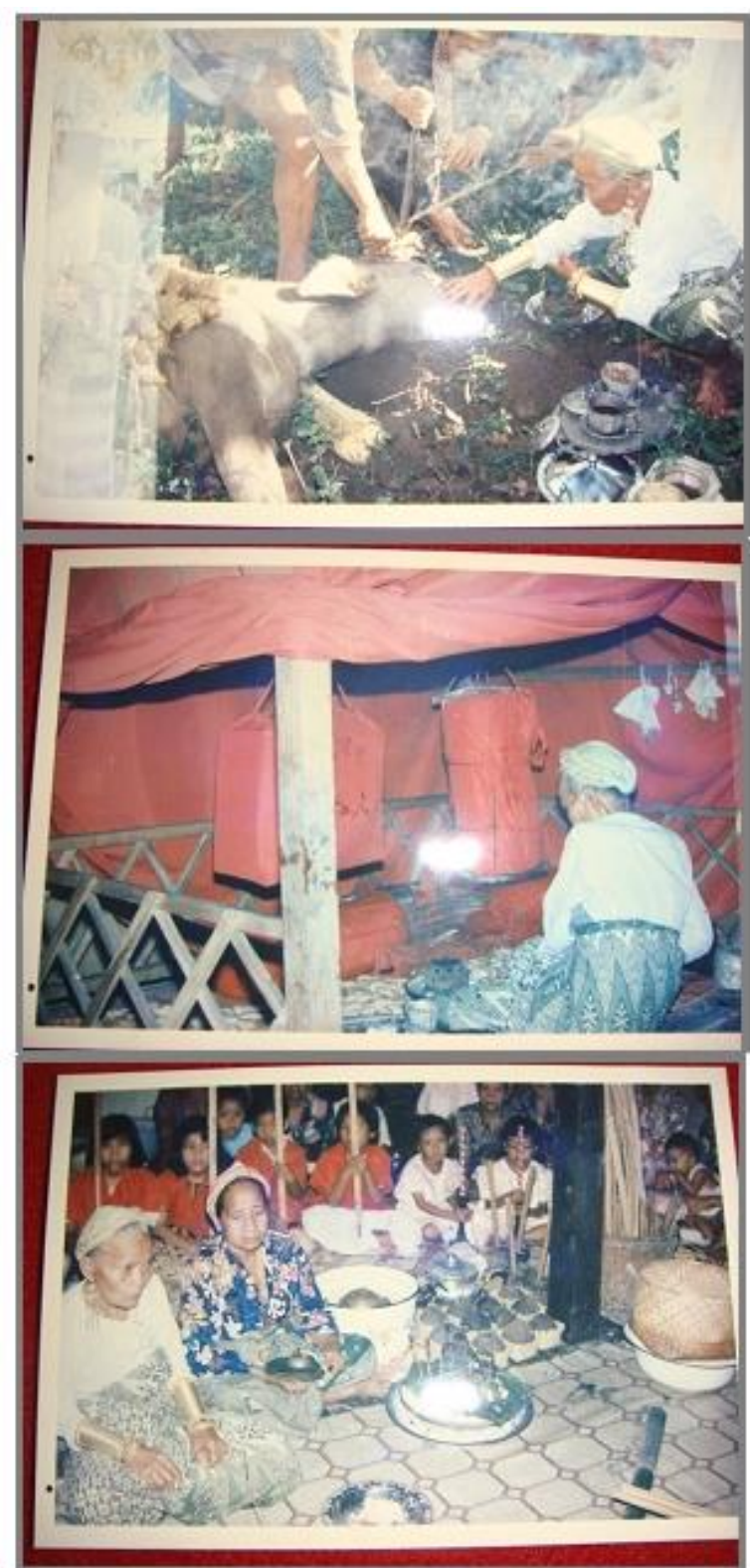
(makkabeka'), menyiapkan benih (mappatinro bine), sampai pada saat akan memulai memanen padi (mappamula mengngala).

\section{b. Mappadendang}

Mappadendang adalah salah satu tradisi suka cita yang berlanjut sampai sekarang, ritual ini merupakan pengucapan syukur masyarakat petani atas keberhasilan panen padi mereka. Ritual ini dilaksanakan secara bersama- sama, masyarakat tetangga kampung datang untuk mengadakan pesta mappadendang, berkumpul di suatu tempat tertentu, kadang di sawah, di halaman Saoraja atau di lapangan. Tergantung kesepakatan antara masyarakat petani, pemerintah maupun pemangku adat (Addatuang). pada saat pesta mappadendang, berbagai macam permainan menyertai diantaranya adalah; ayunan (mattojang/mappere'), main layangan (mappasajang), pajoge', massempe, mallanca, dan disertai kesenian berupa kecapi. Sama seperti ritual mappalili, di masa lalu tempat pelaksanaan ritual mappadendang dilaksanakan di tempattempat yang dianggap sakral atau dikeramatkan.

Mappadendang sebagai ucapan rasa syukur masyarakat petani padi sejak dahulu, biasanya dilaksanakan setelah mendapakan hasil panen padi, dan dilaksanakan tiap tahun pada musim kemarau pada malam hari saat bulan purnama, namun pada saat sekarang mappadendang tidak lagi dilaksanakan pada malam hari, tetapi dilaksanakan pada siang hari. Pola perubahan waktu pelaksanan, telah merubah nilai sakral ritual itu sendiri. Masyarakat petani tidak lagi menganggap sakral, tetapi hanya sebagai ajang berkumpul, bersukaria bersama para masyarakat petani sawah setelah panen raya.

\footnotetext{
${ }^{5}$ Versi lain menyebut komponen utama dalam acara ini yaitu 6 perempuan, 3 pria, bilik baruga, lesung, alu, dan pakaian tradisional yaitu baju Bodo. Lihat Abdul Rahim, 2016. Nilai-nilai Sistem Perekonomian
}

Pada saat hasil panen sudah dikumpulkan di rumah, sebelum dinaikkan pada tempat khusus yang biasa disebut dengan lumbung padi (lanrang) khusus untuk raja, dan (rakkeang) untuk masyarakat biasa, rakkeang adalah bagian atas rumah panggung Bugis. Khusus untuk lumbung padi bagi raja (lanrang), dibuatkan cukup besar dan tersendiri, ini disebabkan para raja jaman dahulu memiliki lahan persawahan yang cukup luas. Maka dilaksanakanlah yang namanya mappadendang sebagai bentuk kesyukuran atas hasil panen padi yang melimpah.

Peralatan $^{5}$ yang dipakai, adalah lesung kayu berbentuk persegi panjang (palungeng), hampir menyerupai bentuk perahu, dengan enam batang kayu panjang bulat $(a l u)$, berukuran satu meter setengah, sebagai alat untuk menumbuk padi di dalam lesung, Pemain terdiri dari wanita dan pria dengan memakai perlengkapan baju adat Bugis/Makassar. Perempuan memakai baju bodo dengan sarung sutra, untuk laki-laki memakai jas tutup warna hitam dengan tutup kepala berupa sarung yang dililit (passapu) atau songko' to Bone. Jumlah pemain terdiri dari dua orang laki-laki bertindak sebagai pemimpin, masing-masing berada pada kedua ujung lesung, untuk mengatur irama atau ritme dan tempo dengan menggunakan alu, sedangkan yang menumbuk pada lesung adalah perempuan yang sudah mahir dan berpengalaman berjumlah empat sampai enam orang. Biasanya dua orang laki-laki melakukan tari-tarian berputar mengelilingi para perempuan yang sedang menumbuk lesung. Pada saat mappadendang, suara lesung dengan alu saling bertautan dan mengeluarkan bunyi-bunyian yang berirama, dan irama yang bertalu talu menjadi penyemangat bagi masyarakat petani yang telah bekerja keras selama proses pengolahan sawah.

Islam dalam Ritual "Mappadendang " dalam Jurnal Hukum Islam Volume 14, No. 1, Juni 2016, hal. 93110 . 
Fungsi ritual mappadendang adalah manifestasi kegembiraan yang sangat dalam dan rasa syukur kepada Yang Maha Kuasa, atas apa yang telah dikerjakannya menghasilkan hasil panen yang melimpah, saling menjaga hubungan tali silaturahmi antar keluarga, tetangga maupun kepada pemerintah setempat, juga sekaligus sebagai sarana hiburan bagi seluruh masyarakat petani yang telah bekerja dengan keras. Berkumpul menjadi salah satu bentuk untuk saling menjunjung rasa solidaritas, kebersamaan dalam kegembiraan, suasana demikian diharapkan dapat menciptakan suasana damai, tentram, nyaman dan tetap saling menghargai, dan saling hormat menghormati, dalam kehidupan bermasyarakat. Selain itu, mappadendang juga menyimpan filosofi yang sangat tinggi dan merupakan sarana nenek moyang dalam memperkuat persatuan dan kesatuan, pentingnya kerjasama, serta membentuk masyarakat dengan tatanan sosial yang solid (Rahim, 2016, p. 108).

\section{Transformasi Budaya Pertanian}

Budaya pertanian dimaksud adalah aspek-aspek budaya yang terkait dengan pertanian seperti kebijakan pemerintah yang berhubungan dengan pertanian, sistem gotong royong, cara menentukan waktu tanam, alat-alat yang terkait dengan pertanian, sistem sosial masyarakat, tenaga kerja, pembagian hasil, sistem pewarisan dan ritual yang berhubungan dengan pertanian. Pada bagian ini, transformasi budaya pertanian diawali dengan kebijakan pemerintah yang berhubungan dengan pertanian.

Sebelum masyarakat Ajattappareng mengenal sistem pertanian modern, kekuasaan dipegang oleh raja. Inisiatif peningkatan hasil pertanian padi dipelopori oleh para raja [wawancara dengan Andi Suddini dan Petta Saleh] dengan cara pembuatan teppo dan Salo Kae (Sungai buatan yang digali secara bergotong royong) untuk keperluan irigasi. Dalam struktur kerajaan-kerajaan di Ajatappareng, terdapat jabatan Matoa Paggalung, semacam menteri yang membidangi pertanian dan mengurus waktu menanam padi, mappalili, penentuan bibit, pengairan dan ritual mappadendang (Lontara' Petta Saleh). Hirarki ini kemudian menghilang bersamaan dengan pergantian pemerintahan pada Periode Kemerdekaan.

Transformasi sistem penggarapan sawah juga terjadi. Berdasarkan beberapa informan, sistem gotong royong telah mulai ditinggalkan sejak sekitar tahun 1990-an di wilayah Ajatappareng, digantikan oleh sistem penggarapan sawah secara individual. Bersamaan dengan itu, pembukaan lahan persawahan baru oleh para raja (makkabekka') dan pengerjaan sawah raja dengan sistem bagi hasil (matteseng) juga semakin ditinggalkan. Sistem pengerjaan sawah yang bersifat kolektif juga semakin ditinggalkan bersamaan dengan berpindahnya tanggung jawab kolektif menjaga kestabilan irigasi kepada pemerintah. Pudarnya sistem gotong royong memang tidak berpengaruh besar pada produksi beras tetapi membuka jalan menuju persaingan antar petani.

Penentuan waktu tanam padi juga telah mengalami perubahan di wilayah Ajatappareng. Berdasarkan naskah lontara dan studi etnografi, cara menentukan waktu tanam pada masa sebelum kemerdekaan adalah dengan cara-cara tradisional. Sekitar tahun 1970-an atau sebelumnya, perhitungan waktu tanam padi menggunakan perhitungan bintang yang disebut pananrang, yaitu tradisi yang melembaga dan ditulis oleh masyarakat dalam banyak naskah lontarak. Lepasnya ketergantungan terhadap musim hujan karena ketersediaan irigasi menyebabkan perhitungan tradisional tentang waktu tanam padi tidak lagi bersifat fungsional.

Alat-alat yang digunakan dalam kegiatan pertanian juga mengalami perubahan yang sangat cepat di wilayah Ajatappareng dibandingkan dengan beberapa komunitas Bugis di wilayah 


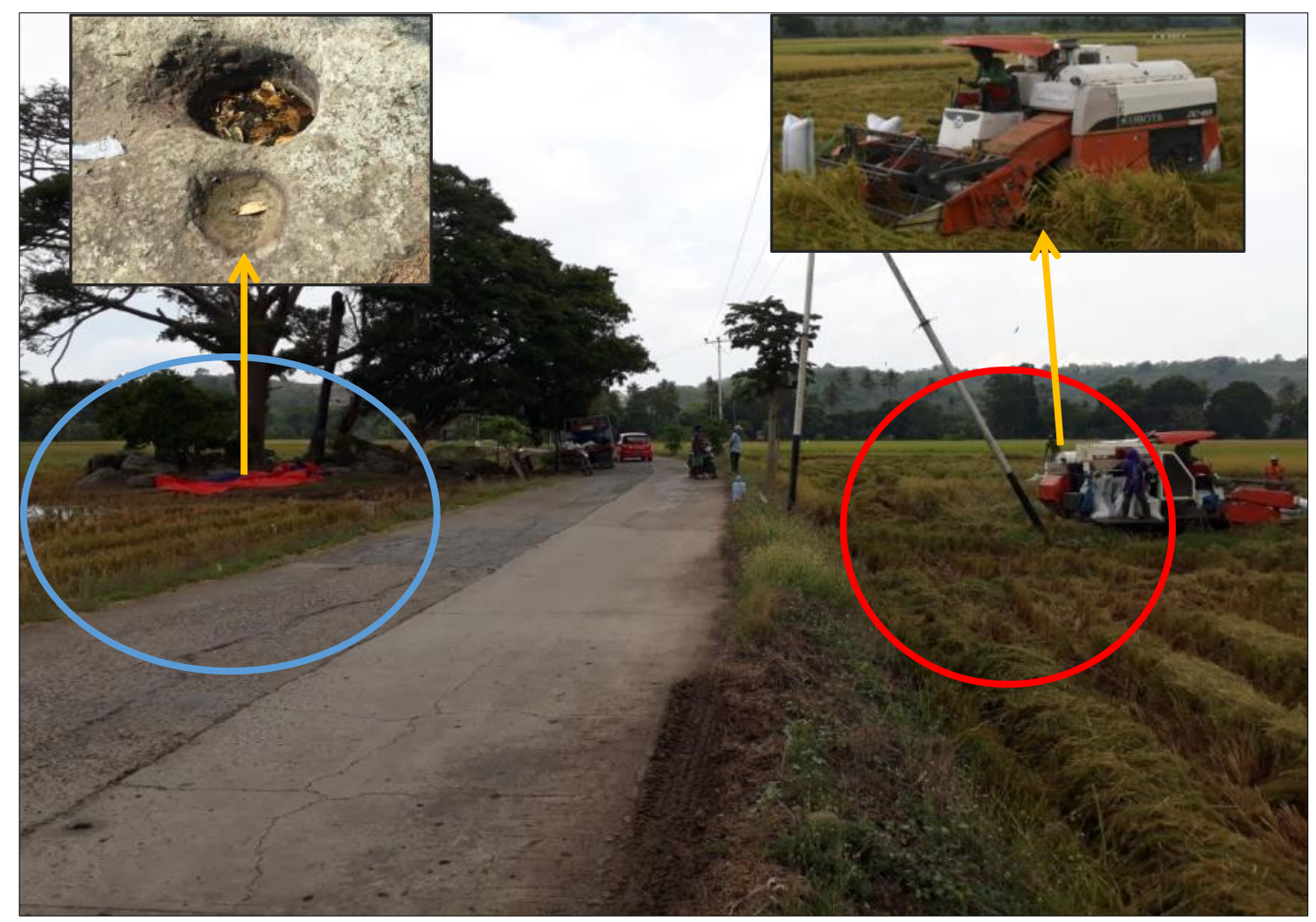

Gambar 5. Gambaran tentang transformasi budaya pertanian. Mobil pemanen padi yang bekerja dekat sebuah lumpang batu. Saat ini, harapan terhadap hasil panen salah satunya bergantung pada ketepatan waktu panen oleh mobil/mesin kombain. Jauh sebelumnya, pengharapan terhadap hasil panen yang melimpah bergantung pada pelaksanaan ritual mappalili yang sering dilaksanakan di tempat-tempat keramat (salah satunya adalah di lokasi Lumpang Batu) (Sumber: Dokumentasi Balai Arkeologi Sulawesi Selatan, 2018).

pedalaman lain di Sulawesi Selatan. Sebagai contoh, penggunaan tenaga hewan (kerbau atau sapi) untuk melakukan pembajakan sawah sudah tidak dilakukan sejak tahun 1990-an dan hingga sekarang masih banyak masyarakat petani di wilayah pedalaman Sulawesi Selatan masih memakainya. Sekarang, masyarakat Ajatappareng menggunakan traktor tangan (dompeng) untuk membajak dan menggemburkan tanah pertanian. Alat traktor tangan jauh lebih efektif dan efisien dibandingkan menggunakan kerbau yang semakin sulit diternakkan karena semakin sempitnya sumber makanan ternak (gambar 5).

Jika dua puluh tahun lalu, kuda pengangkut (nyarang patteke) berfungsi penting untuk mengangkut hasil panen dari sawah ke jalan, sekarang pemandangan itu tidak dijumpai lagi. Sepeda motor modifikasi yang disebut tassi telah menggantikan fungsi kuda atau nyarang patteke. Jika dahulu setiap petani memiliki minimal satu ekor kuda untuk mengangkut hasil panen, sekarang para petani menyerahkan pengangkutan hasil panen kepada jasa tassi. Karena panen dapat berlangsung lima kali dalam dua tahun maka kondisi tersebut merangsang munculnya satu lapangan kerja baru di Ajatappareng.

Sekitar tiga puluh tahun lalu, masyarakat masih memanen sendiri padi mereka dibantu oleh kerabat dan keluarga. Terjadi perubahan saat itu dimana jasa tenaga kerja pemanen (passangki) mengambil alih karena lebih cepat. Para passangki yang telah dikoordinir berdatangan dari berbagai daerah dan 
dengan cepat memanen padi-padi di sawah. Dalam lima tahun terakhir, jasa mobil pemanen padi mulai marak digunakan dan sedikit demi sedikit menggantikan jasa passangki. Ketika musim panen tiba, beberapa masyarakat Ajatappareng menawarkan jasa mobil pemanen (sering disebut oleh masyarakat setempat dengan istilah kombain padi yang bekerja jauh lebih cepat dan murah.

Gambaran transformasi budaya pertanian padi di wilayah Ajatappareng berlangsung sangat cepat dalam rentang waktu tiga puluh tahun terakhir. Masyarakat Ajatappareng memang telah mengidentikkan dirinya sebagai masyarakat surplus padi dan letaknya pada pesisir barat juga merupakan faktor kunci cepatnya perubahan di wilayah ini.

\section{Pudarnya Ritual Pertanian}

Ritual pertanian di Ajatappareng dilakukan pada dua momen, pertama adalah ritual mappalili, ritual yang menandai awal kegiatan pertanian, dan kedua adalah ritual mappadendang, ritual kesyukuran setelah panen dilaksanakan. Antara kegiatan mappalili dan mappadendang, terdapat beberapa ritual kecil yang dipimpin oleh Sanro wanua dan hanya melibatkan beberapa orang saja, misalnya ritual maddoja bine, massisi atau malleppe ase. Tempat pelaksanaan upacara mappalili dan mappadendang adalah tempat keramat yang biasanya berhubungan dengan tempat kemunculan awal atau kuburan tokoh legenda pada satu kerajaan. Sebagai contoh di Suppa, tempat akhir persembahan kepala kerbau yang telah dikurbankan dalam ritual mappalili dan mappadendang adalah Lawaramparang, suatu mata air di pinggir Pantai Suppa yang dipercaya sebagai tempat munculnya Tomanurung Suppa.

Sampai sekarang, ritual mappalili dan mappadendang masih dilakukan pada beberapa bekas pusat kerajaan besar seperti Sawitto, Sidenreng, Rappang, Alitta dan Suppa serta pada beberapa Kerajaan Palili dari lima kerajaan besar di Ajatappareng tersebut. Meskipun demikian, seiring perjalanan waktu, besaran kedua ritual tersebut semakin berkurang. Beberapa bagian ritual disederhanakan, pergantian dengan unsur-unsur baru dan pemeran ritual juga mengalami perubahan. Bagian ritual yang disederhanakan misalnya ritual maddojabine, masisi atau malleppe ase biasa tidak dilakukan lagi. Beberapa tempat di wilayah Ajatappareng menunjukkan bahwa rangkaian ritual antara mappalili dan mappadendang mulai ditinggalkan.

Pergantian unsur-unsur lama oleh unsur baru dalam ritual mappalili juga terjadi misalnya di wilayah Akkarungeng Lanriseng, Kabupaten Pinrang, rakkala atau alat pembajak tidak lagi digunakan dalam ritual mappalili sejak tahun 1990-an, digantikan oleh traktor tangan atau disebut dompeng, juga di Desa Ciro-Ciroe, Kecamatan Watang Pulu, Kabupaten Sidrap (Asrianensi, 2014). Pelaksana atau pemimpin ritual juga mengalami perubahan pada hampir semua Akkarungeng di Ajatappareng dimana peran para raja dan bangsawan berpindah kepada pemerintah (Kepala Desa, Camat, Bupati). Para bangsawan dan hirarki kerajaan yang memang sudah memudar tidak lagi mendapat tempat khusus, digantikan oleh pemeran-pemeran yang memiliki modal besar, kekuasaan, jabatan atau kecendekiawanan.

\section{PENUTUP}

Tradisi pertanian di wilayah Ajatappareng telah berlangsung selama berabad-abad, proses ini pun telah melahirkan sistem pertanian yang dilaksanakan secara turun temurun. Tradisi pertanian ini sekaligus menunjukkan bahwa sistem kepercayaan menjadi bagian yang tidak terpisahkan dalam pengetahuan sistem pertanian masyarakat di masa lalu. Dalam prosesnya pula, terjadi berbagai perubahan tidak hanya teknik pertanian (misalnya memanfaatkan kemajuan ilmu dan 
teknologi), namun perubahan-perubahan ini juga menyentuh aspek intangible yaitu ritual-ritual pertanian.

Tradisi pertanian di masa lalu sangat menggantungkan pengharapan masyarakat (petani) akan hasil panen yang melimpah pada berbagai bentuk ritual yang harus mereka laksanakan. Pengharapan akan hasil panen yang baik juga sangat bergantung pada kepatutan masyarakat petani pada petuah-petuah dan aturan-aturan yang sudah dijalankan secara turun-temurun. Dalam konteks sistem pertanian tradisional seperti ini para penguasa menjadi inisiator utama dalam mempertahankan serta meningkatkan produksi beras. Salah satu bentuk dari upaya tersebut adalah melalui mistifikasi ritual yang diinisiasi oleh pihak penguasa atau kerajaan, yaitu Akkarungeng, Arajang, dan Addatuang.

Saat ini, sistem pertanian yang dijalankan secara tradisional di Ajatappareng sudah sangat sulit ditemui, informasi-informasi yang diperoleh lebih kepada ingatan-ingatan personal yang dulunya menjalankan tradisitradisi pertanian beberapa dekade sebelumnya. Disadari bahwa perkembangan ilmu pengetahuan dan teknologi telah menuntut berbagai perubahan, terlebih tuntutan terhadap upaya peningkatan produktivitas hasil pertanian. Namun di sisi lain, ingatan-ingatan tentang tradisi pertanian dan sistem pertanian tradisional secara umum penting menjadi rekaman pengatahuan untuk disampaikan kepada generasi muda. Demikian pula mengamati tren global saat ini yang mengedepankan pengelolaan kawasan pertanian pangan berkelanjutan.

\section{Ucapan Terima Kasih}

Draft awal naskah ini adalah bagian (data etnografi) dari Laporan Penelitian "Irigasi Ajatappareng: Menelusuri Jejak Sejarah Pertanian di Sulawesi Selatan", yang didanai oleh DIPA Balai Arkeologi Sulawesi Selatan. Penulis mengucapkan terima kasih kepada seluruh anggota tim (Dra. Muhaeminah; Asmunandar, S.S., M.Hum; Nur. Ihsan Djindar, S.S., M.Hum; Lendrawati, S.S; Andika Saputra; dan Muh. Ikram, M. S.S), serta semua pihak yang telah membantu pelaksanaan penelitian, Drs. H. Alimin (Kabid. Kebudayaan Dinas Dikbud Kab. Pinrang), dan Bahtiar, S.S (Staf Dinas Dikbud Kab. Sidrap); juga kepada seluruh informan: Drs. Andi Muhammad Saleh Pasanrangi (Sidenreng), Drs. Andi Suddini (Talabangi), Yukkas, S.Pd. (Letta), H. Andi Monji (Suppa), La Sewa (Lerang, Sawitto), La Nohong (Alitta), Wa' Onding (Mojong, Sidenreng), La Midding (Bangkai, Sidenreng). 


\section{DAFTAR PUSTAKA}

Afandi, M. Z., Arjani, N. L., \& Kaler, I. K. (2017). Ritual Neduhin dalam Sistem Pertanian Masyarakat Desa Bunutin, Kecamatan Kintamani, Kabupaten Bangli, Bali. Jurnal Humanis, 21(1), 37-45. Retrieved from https://ojs.unud.ac.id/index.php/sastra/article/view/35418

Asrianensi, J. (2014). Studi tentang Tradisi Mappalili pada Masyarakat Desa Ciro-Ciro'e Kecamatan Watang Pulu Kabupaten Sidenreng Rappang. Jurnal Tomalebbi, 1(1), 4146.

Badaruddin, M., Mappasere, S. K. R., \& Aminullah, A. (1986). Sistem Ekonomi Tradisional sebagai Perwujudan Tanggapan Aktif Manusia terhadap Lingkungannya: Daerah Sulawesi Selatan. Ujung Pandang: Proyek Inventarisasi dan Dokumentasi Kebudayaan Daerah Sulawesi Selatan, Departemen Pendidikan dan Kebudayaan.

Bahfiarti, T. (2011). Mistifikasi 'Bissu' dalam Upacara Ritual Adat Etnik Bugis Makassar (Kajian Studi Dramaturgi). Jurnal Ilmu Komunikasi, 1(2), 159-170.

Baoesat, A. (2006). Terdjemahan Lontarak Latowa: Hadat Besar Keradjaan Rappeng, Djilid I (H. A. M. S. Pasanrangi, Ed.).

BPSP. (2018). Luas Panen, Produksi, dan Produktivitas Padi Sawah dan Padi Ladang Menurut Kabupaten/Kota di Provinsi Sulawesi Selatan 2015. Makassar: Badan Pusat Statistik Provinsi Sulawesi Selatan.

Bulbeck, D., \& Caldwell, I. (2008). Oryza Sativa and The Origins of Kingdoms in South Sulawesi, Indonesia: Evidence from Rice Husk Phytoliths. Indonesia and the Malay World, 36, 1-20. https://doi.org/10.1080/13639810802016117

Cortesao, A. (2015). Suma Oriental: Karya Tome Pires: Perjalanan dari Laut Merah ke Cina dan Buku Francisco Rodrigues (Edisi Terj; Adrian Perkasa \& A. Pramesti, Eds.). Yogyakarta: Ombak.

Druce, S. C. (2005). The Lands West of The Lakes: The History of Ajattapareng, South Sulawesi, AD 1200 to 1600. The University of Hull.

Fajriyani, G. (2015). Upacara Mappalili oleh Pa'Bissu di Kelurahan Bontomate'ne Kecamatan Segeri Kabupaten Pangkep. Universitas Islam Negeri Alauddin Makassar.

Hasanuddin. (2015). Kebudayaan Megalitik di Sulawesi Selatan dan Hubungannya dengan Asia Tenggara. Universiti Sains Malaysia.

Khaedir. (2018). Makna Ritual Mappalili oleh Komunitas Bissu Bugis di Pangkep. Universitas Islam Negeri Alauddin Makassar.

Latif, A. (2014). Para Penguasa Ajatappareng: Refleksi Sejarah Sosial Politik Orang Bugis. Yogyakarta: Ombak.

Macknight, C. C. (1983). The Rise of Agriculture in South Sulawesi Before 1600. Review of Indonesian and Malaysian Affairs, 17, 92-116. Retrieved from http://www.oxis.org/articles-k-z/macknight-campbell/macknight-1983.pdf 
Mansyur, S., Somba, N., Muhaeminah, Nur, M., Asmunandar, \& Djindar, N. I. (2018). Irigasi Ajatappareng: Menelusuri Jejak Sejarah Pertanian di Sulawesi Selatan. Makassar.

Maulida, R. (2017). Rabu Nehah (Studi Etnografi tentang Larangan Turun ke Sawah pada Masyarakat Gampong Paloh Kayee Kunyet, Kecamatan Nisam). Aceh Anthropological Journal, 1(1), 57-59. $\quad$ Retrieved from http://ojs.unimal.ac.id/index.php/AAJ/article/view/360

Moleong, L. J. (2008). Metodologi Penelitian Kualitatif (Edisi Revi). Bandung: PT Remaja Rosdakarya.

Morris. (1982). Celebes en Onderhoorigheden. In Koloniaal Verslag van 1892, Nederland Oost Indie, Bijlage C, Tweede Kamer. Makassar: De Gouverneur van Celebes en Onderhoorigheden.

Nurung, R. M., \& Pratiwi, J. D. (2011). Motivasi Petani dalam Mempertahankan Sistem Tradisional pada Usaha Tani Padi Sawah di Desa Parbaju Julu, Kabupaten Tapanuli Utara, Provinsi Sumatera Utara. Jurnal Agrisep: Kajian Masalah Sosial Ekonomi Pertanian Dan Agribisnis. https://doi.org/https://doi.org/10.31186/jagrisep.10.1.51-62

Pabitjara, B. (2006). Persekutuan Limae Ajatappareng Abad XVI”. Tesis Magister. Makassar. Universitas Negeri Makassar.

Pelras, C. (2006). Manusia Bugis (Terjemahan; Abdul Rahman Abu, Hasriadi, \& N. Sirimorok, Eds.). Jakarta: Nalar bekerjasama dengan Forum Jakarta-Paris, EFEO.

Poelinggomang, E. L. (2002). Makassar Abad XIX: Studi tentang Kebijakan Perdagangan Maritim. Jakarta: Kepustakaan Populer Gramedia bekerjasama dengan Yayasan Adikarya dan The Ford Foundation.

Purwanto, Y. (2010). Studi Sistem Pertanian Tradisional Masyarakat Negeri Saleman, Sera Utara, Kabupaten Maluku Tengah. In Laporan Penelitian COLUPSIA Project, CIRAD dan UNI EROPA. Collaborative Land Use Planning and Sustainable Institutional Arrangements for Strengthening Land Tenure, Forest and Community Rights in Indonesia. Retrieved from http://www1.cifor.org/fileadmin/subsites/colupsia/documents/Studi_Sistem_Pertanian_ Tradisional_YP.pdf

Rahim, A. (2016). Nilai-nilai Sistem Perekonomian Islam dalam Ritual 'Mappadendang. Jurnal Hukum Islam, 14(1), 93-110.

Sartini, N. W. (2017). Makna Simbolik Bahasa Ritual Pertanian Masyarakat Bali. Jurnal Kajian Bali, 14(1). https://doi.org/https://doi.org/10.24843/JKB.2017.v07.i02.p06

Somba, N., \& Nur, M. (2016). Tradisi Bercocok Tanam di Kabupaten Soppeng. In Hasanuddin \& B. A. K.W. (Eds.), Lembah Walennae: Lingkungan Purba dan Jejak Arkeologi Peradaban Soppeng. Yogyakarta: Ombak. 
Tim Penelitian. (2012). Laporan Penelitian Arkeologi: Pembuktian Arkeologi terhadap Toponim dalam Naskah Ajatappareng di Kabupaten Pinrang. Makassar. 